\title{
Islamic Law Perspective on the Use of Incense in Thanksgiving Events at the Balabe Customs in Kailinese Ethnic
}

\author{
Hikwan Wahyudi ${ }^{*}$, Ubay Harun ${ }^{2}$, Muhammad Taufik ${ }^{3}$ \\ ${ }^{1}$ Islamic Family Law Department, Postgraduate, Institut Agama Islam Negeri Palu \\ ${ }^{2}$ Islamic Family Law Department, Postgraduate, Institut Agama Islam Negeri Palu \\ ${ }^{3}$ Islamic Family Law Department, Postgraduate, Institut Agama Islam Negeri Palu
}

ABSTRACT

The traditional Balabe or Nolabe in the thanksgiving event is an asset of cultural wealth in Central Sulawesi, Indonesia. The Balebe or Molabe custom is carried out every time there are celebratory activities such as weddings, mourning, childbirth and others. This study aims to provide knowledge and understanding of the process of using incense in the implementation of the Balabe custom and how to review Islamic law on the tradition. This study uses a qualitative approach, namely research procedures that produce descriptive data in the form of written or spoken words from people related to the people in Palupi, especially the Kaili tribe. The data collection techniques used in this research are observation, interview, and documentation techniques. Furthermore, after the data is collected, the data obtained needs to be analyzed in three stages that run in cycles: data reduction, data presentation, and drawing conclusions or verification. The results of this study indicate that basically, the major schools of jurisprudence agree to accept customs as the basis for the formation of law. However, in terms of numbers and details, there are differences of opinion between these schools, so that 'urf is included in the group of disputed arguments among scholars. The research implies that it is hoped that all leaders, the community and local government officials will maintain and preserve the bolabe tradition in order to survive even in the face of today's times.
ARTICLE

INFORMATION

\section{Keywords:}

Islamic law, custom, Kaili ethnic, thanksgiving, social events 


\section{Introduction}

The diversity of the Indonesian people, known as ethnicity, religion and race, has existed since a long time ago due to the different origins of descent, residence and natural environment mixed with the indigenous culture of the local community. The indigenous culture is known as adat.

Adat is a habit that is a culture and cannot be separated from people's lives, so the meaning adat needs to be interpreted wisely because it is a cultural heritage passed down from generation to generation into a community habit the adat needs to be preserved. ${ }^{1}$ Traditions that grow and develop in our society are interpreted as an effort to organize a safe, peaceful, and prosperous community life.

Customary law is categorized as unwritten law, which is defined as law that is still alive in people's beliefs, but it is not written, but its validity is obeyed like legislation.

Adat comes from Arabic which means the repetition of an event but regardless of the good or bad judgment. So that there is no difference in principle between adat and urf, because both of them refer to events that are repeatedly carried out so that they are recognized and known by people. Then, the law

1 Pribadi, M., \& Nurdin, N. (2021). The Practice of Salawat Nariyah in Rural Javanese Society Indonesia: Religiosity or Sociality? Review of International Geographical Education Online, 11(5), 2545-2555. based on the urf can change according to the changing times. ${ }^{2}$

Adat has a very large influence in the formation of Islamic law because many laws are based on maslahah, while maslahah itself can change with changing situations and conditions. However, the law referred to here is a law that is ijtihadiy and does not have an explicit text reference, such as the permissibility of bai' al-mu'athah. Urf or custom can also be a reference in interpreting mujmal texts or texts and explaining things that do not have the criteria of syar'i. ${ }^{3}$

The custom is accepted by people because it contains benefits. Not using custom does not accept benefit, because the scholars have agreed on the necessity to take something that is of value to benefit even though there is no text. The relation with custom in the view of Islamic law refers to a grouping when viewed from its scope, namely special urf. It means a habit or custom that is carried out by a group of people in a particular place or at a certain time and does not apply at any time and place. ${ }^{4}$ So that this customary classification has been in effect for a long time in the Balabe or Molabe customs of the Kaili Tribe.

The Kaili tribe is one of the ethnic groups that inhabit Central Sulawesi, especially Palu. The Kaili people highly

\footnotetext{
2Sapiudin Shidiq, Ushul Figh, Cet. 2, (Jakarta: Kencana, 2014), 98-102

${ }^{3}$ Faiz Zainuddin, Konsep Islam Tentang Adat: Telaah Adat dan Urf Sebagai Sumber Hukum Islam, Vol. 9, No. 2, (Situbondo: Jurnal Lisan AlHal, 2015), 405. (Diakses 05 April 2020)
}

${ }^{4}$ Ibid, 405.

e-ISSN: 2715-4580 p-ISSN: 2715-8268 
respect their customs. With the Kaili tribe's customs which are still preserved until now, they often carry out these customs such as during certain thanksgivings such as entering a new house, new vehicle, and others.

The Kaili tribe in Palu still upholds its existence and maintains its sustainability. ${ }^{5}$ One of the cultural customs in the Aili community that is upheld by Balabe or Molabe this custom is a characteristic of the Kaili tribe who inhabit the valley of Palu. Several traditional Balabe or Molabe cultural celebrations are usually carried out by the people who attend the event. The influence of Kaili cultural values in each of these celebrations is still strong in the community.

The custom of Balabe or Molabe in a large prayer event is an asset to the cultural wealth of the people of Central Sulawesi. Balabe or Molabe in Indonesian is sitting with several people attended by traditional leaders and the local mosque imam as a community shop where incense and trays are inside. This culture is carried out in the midst of the Kaili Tribe community, where every prayer to God is to express gratitude for the sustenance that Allah SWT has given to his people. The Balebe tradition is carried out every time there are celebratory activities such as weddings, mourning, childbirth, and others.

${ }^{5}$ Handayani, A. M. S., \& Nurdin, N. (2021). Understanding Women's Psychological WellBeing in Post-Natural Disaster Recovery. Medico Legal Update, 21(3), 151-161.

\section{Literature Review}

\subsection{Definition of Custom}

Custom, according to the term, is a problem that is repeated without being related to reason, but if an action is repeated with reason in the sense that repetition is judged by reason, then this is called a logical consequence (talazumun aqliyun), it is not custom, for example, the movement of a ring is caused by the movement of a finger, or where there is smoke there must be fire because the logical reason will judge these problems. Then, the term of customary law itself comes from the Arabic terms $h u k^{\prime} m$ and adah. The word huk'm, whose plural is ahakam which means an order, while the word adah means habit. So customary law is a customary rule. In Indonesia, customary law is defined as original Indonesian law that is not written in the form of legislation of the Republic of Indonesia, which contains elements of religion. ${ }^{6}$

The terminology of custom and customary law is often mixed up in giving an understanding, even though the two are like different institutions. Adat is often seen as a tradition so that it seems very local, outdated, not in accordance with religious teachings and others. This is understandable because custom is a rule without any real sanctions (punishments) in the

${ }^{6}$ Fatahuddin Aziz Siregar, Ciri Hukum Adat dan Karaktristiknya, Vol. 4 No. 2, (IAIN Padangsidimpuan: Jurnal Al-Maqasid, 2018), 3. (Diakses 05 April 2020)

e-ISSN: $2715-4580$ p-ISSN: $2715-8268$ 
community, except for the matter of customary sins, which are closely related to matters of taboo to do (taboo and kualat). Moreover, the terms cultural customs, and others appear. ${ }^{7}$

The definition of the term 'urf according to the fuqaha is something that is known to each other by the community, and they are used to it, both in speech and action and have been done continuously or by the majority of people. While the ushuliyyün distinguishes between custom and 'urf in discussing its position as one of the arguments for establishing sharia law.' Custom is defined as something that is done repeatedly without any rational relationship. This definition explains that custom is all actions that are not carried out without considering reason. In other words, if the act is carried out with consideration of reason, then it is not called custom. In addition, customs also include habits carried out by individuals in society. So it can be said that custom has a broad scope, which includes individual habits as individuals who live in the midst of society as well as habits carried out by a community.

The terms 'urf and custom according to the ushuliyyun have differences between the two. According to ushuliyyūn is a habit that is considered good in quotes or deeds. Based on this, it is understood that 'urf is part of adat. In the sense that there is almost no difference in understanding between 'urf and adat, but in the usual sense, it means that the notion of 'urf is more general than the meaning of custom because

7Ibid, 3. besides being known by the community, adat is also commonly practiced among them as if it will have been a written law, so there are sanctions against people who violate it. ${ }^{8}$ From the difference in terms of 'urf and custom, the view according to Syekh Jalaluddin explains that customary law is a link between the past and the later, on the part of their existence or absence as seen from things that are done repeatedly. Customary $1^{9}$ aw does not lie in the event but in what is not written behind the event. What is not written is a mandatory provision behind the facts that demand linking an event to another event. ${ }^{10}$

Based on the above definition, it can be seen that the basic difference between adat and 'urf has access to the consequences of their position and has an impact on legal application. Therefore, the ushuliyyun emphasized the discussion of 'urf as a method of legal istinbath, not through custom. ${ }^{11}$

The scholars believe that the terms adat and 'urf have the same meaning.

8Jaya Miharja, Kaidah-Kaidah Al-'Urf dalam Bidang Muamalah, Vol. IV, No. 1, (STAI Nurul Hakim Kediri Lombok Barat: Jurnal ElHikam, 2011), 106. (Diakses 05 April 2020)

${ }^{9}$ Rasyid, N. A., \& Nurdin, N. (2021). The Diaspora of the Sufis in Indonesia: Moving From Western to Eastern Islands. International Journal of History and Philosophical Research, 9(1), 33-45.

${ }^{10}$ Syekh Jalaluddin menjelaskan tentang hukum adat dapat dilihat pada jurnal yang dibuat oleh Fatahuddin Aziz Siregar, Ciri Hukum Adat dan Karaktristiknya, Vol. 4 No. 2, (IAIN Padangsidimpuan: Jurnal Al-Maqasid, 2018), 4. (Diakses 05 April 2020)

11Jaya Miharja, Kaidah-Kaidah Al-'Urf dalam Bidang Muamalah, Vol. IV, No. 1, (STAI Nurul Hakim Kediri Lombok Barat: Jurnal El-Hikam, 2011), 106. (Diakses 05 April 2020)

e-ISSN: $2715-4580$ p-ISSN: $2715-8268$ 
This is based on the definition of figh scholars who mean:

'Urf is something that is considered common by humans and continues to be enforced, be it in the form of speech or movement and that is also called adat. ${ }^{12}$

From the information above, it can be concluded that the meaning of this rule according to the terms of the scholars is that a custom and 'urf can be used as a basis for establishing syar'i law if there is no syar'i text or lafadh shorih (firm) that contradicts it.. ${ }^{13}$

\subsection{Customs in Islamic Law}

Customary law is sometimes religious-magical, that is, according to traditional Indonesian beliefs, because every society is filled with supernatural powers that must be maintained in order to remain safe and peaceful. There is no boundary between the world of birth and the unseen world, and there is no separation between various fields of life, such as human life, nature, ancestral spirits, and the life of other creatures.

The existence of worshiping, especially to the spirits of the ancestors, that are the protectors of customs and is needed for the happiness of society, every activity or collective action such as

\footnotetext{
12Beberapa para ulama yang menyebutkan adat dan 'urf mempunyai arti yang sama dapat dilihat pada jurnal yang dibuat oleh Fatmah Taufik Hidayat dan Moh. Izhar Arif Bin Moh. Qasim, Kaedah Adat Muhakkamah dalam Pandangan Islam (Sebuah Tinjauan Sosiologi Hukum), Vol. 9, No. 1, (Jurnal Sosiologi USK, 2016), 70. (Diakses 05 April 2020)

13Ibid, 70.
}

clearing land, building houses, planting, and other important events, religious ceremonies are always held with the aim that the aims and objectives will be blessed and there are no obstacles and always succeed well. In addition, there are customary laws that are cash and concrete in nature. Namely, the transfer of rights and obligations must be carried out at the same time as the surrender and acceptance events must be carried out simultaneously and is intended to maintain balance in social interaction.

Meanwhile, with a concrete pattern, visible signs such as every act or desire in certain legal relationships must be stated with tangible objects so that no promises are paid with promises, everything must be accompanied by concrete actions so that there is no mutual suspicion of one another. ${ }^{14}$

Then to make 'urf as a legal basis, the following conditions must be met:

a. Urf must be generally accepted. This means that 'urf must be understood by all levels of society, both in all regions and in certain areas. Therefore, if it is only the 'urf of the people, of course, it cannot be used as a legal backing.

b. It does not conflict with the syar'i text, nor does it conflict with the nas sabit (fixed) text, other syarak's arguments, and the rules that have been determined by syarak. If it contradicts the case, then of course 'urf is rejected and cannot be used in

14Fatahuddin Aziz Siregar, Ciri Hukum Adat dan Karaktristiknya, Vol. 4 No. 2, (IAIN Padangsidimpuan: Jurnal Al-Maqasid, 2018), 6. (Diakses 05 April 2020)

e-ISSN: $2715-4580$ p-ISSN: $2715-8268$ 
syarak. An example is 'urf in society that a husband must provide a place to live for his wife.' This kind of urf applies and must be done.

c. The 'urf has been around for a long time, not a new 'urf. In this case, for example, if someone says, "For the sake of Allah, I will not eat meat forever." Furthermore, when they said that word, they meant mutton and beef; five years later, society's urf changed that meat meant all meat, including fish meat. Then that person eats fish meat, then that person is not punished for breaking his oath because a lafadh is not based on the 'urf that appears later.

d. Does not conflict with tashrih (one's firmness in a problem). If an 'urf clashes with tashrih, then 'urf does not apply.'15

\section{Methodology}

This study uses qualitative approach $^{16,17}$ investigating the implementation of Kalili ethnic custom

${ }^{15}$ Fatmah Taufik Hidayat dan Moh. Izhar Ariff Bin Moh. Qasim, Kaedah Adat Muhakkamah dalam Pandangan Islam (Sebuah Tinjauan Sosiologi Hukum), Vol. 9, No. 1, (Jurnal Sosiologi USK, 2016), 72-73. (Diakses 05 April 2020)

16 Nurdin, N., \& Yusuf, K. (2020). Knowledge management lifecycle in Islamic bank: the case of syariah banks in Indonesia. International Journal of Knowledge Management Studies, 11(1), 59-80. https://doi.org/10.1504/ijkms.2020.105073

17 Nurdin, N., Stockdale, R., \& Scheepers, H. (2014). Coordination and Cooperation in EGovernment: An Indonesian Local E-Government Case The Electronic Journal of Information Systems in developing Countries, 61(3), 1-21.
Balabe from Islamic perspectives. This study was carried out in Kaili community in Palu, Central Sulawesi, Indonesia. This study also used religion sociological approach ${ }^{18}$ in understanding the implementation of Kaili Balabe custom within th ethnic. Data were collected through field observation, indepth interviewes with Kalinene communities. Written materials were also used to analyze the case. ${ }^{19}$ We also interviewed Kalinese key figures who practiced Balabe custom to understand their experiences. Data analysis consists of several procedures which included reduction and verification techniques with various data sources. ${ }^{20}$ The reduced data is then analyzed reflecting on theoretical concepts used in this study ${ }^{21} 22$.

18 Pribadi, M., \& Nurdin, N. (2021). The Practice of Salawat Nariyah in Rural Javanese Society Indonesia: Religiosity or Sociality? Review of International Geographical Education Online, 11(5), 2545-2555.

19 Nurdin, N. (2018). Institutional Arrangements in E-Government Implementation and Use: A Case Study From Indonesian Local Government. International Journal of Electronic Government Research (IJEGR), 14(2), 44-63. https://doi.org/10.4018/ijegr.2018040104

20 Rusli, R., \& Nurdin, N. (2021). Understanding Indonesia millennia Ulama online knowledge acquisition and use in daily fatwa making habits. Education and Information Technologies. doi: 10.1007/s10639-021-10779-7

${ }^{21}$ Iqbal, M., Rusli, R., \& Musyahidah, M. (2019). Management Strategies of Professional Zakat Funds for Mustahiq Family Welfare By Amil Zakat Body International Journal of Contemporary Islamic Law And Society, 1(1), 39-51.

22 Nurdin, N. (2021). A Collective Action In Indonesia Local E-Government Implementation e-ISSN: 2715-4580 p-ISSN: 2715-8268 


\section{Result and Discussion}

\subsection{Kalinese Custom}

Each tribe must have its own customs. The term tribe is broader than a clan. The combination of various clans is an ethnic group (nation), namely a unitary group of people who are ordained by God, living in an area within the territory of a certain country. Of the many ethnic groups who live in the Valley of Palu, the Kaili tribe dominates. The Kaili (To Kaili) tribe, long before the Dutch East Indies government, already had its own form and system of government, Kagaua. The Kagaua (Kingdom) system is held by a Magau (King) and assisted by an assistant called Madika Malolo (Raja Muda). Then equipped with Madika Matua as Chairman of the Government Council who is responsible to Magau. Then the Madika Matua (Prime Minister) in carrying out his daily duties was assisted by: Punggava, as Minister of the Interior; Galara, as Minister of Justice; Tadulako, as Minister of Defense and Security; Pab talk, as Minister of Information, and Sabandara, as Minister of Transportation. ${ }^{23}$

As executives, they are appointed and dismissed by the Magau (King) at the suggestion, suggestion, and approval of

Success. International Journal of Scientific $\mathcal{E}$ Technology Research, 10(2), 160-166.

${ }^{23}$ Arsyid Musaera, Ketua Adat Kelurahan Palupupi, wawancara, di wawancarai di BTN Palupi Kelurahan Palupi pada Tanggal 12 Juli 2020
Baligau (Chairman of the Customary Council) in a forum or assembly called: Libu $\mathrm{Nu}$ Maradika. In addition, there is also called: Libu Nto Dea. This forum is tasked with formulating and making regulations that apply within the Kagaua (Kingdom). The implementation is led by a member of Baligau (Chairman of the Customary Council) with Kota Pat Member, who are representatives of To Dea (People) from the four corners of Kagaua. And or Pitunggota City, which consists of To Dea representatives in the seven cardinal directions around the kingdom. ${ }^{24}$

Within the Kagaua (Kingdom) system, there are relatively the same customs and various life cycle ceremonies. The customs referred to include: customs related to Harvest Day (no-Vunja), Healing Diseases (no-Balia), Death (no-Vaino), Marriage (no-Rano), and customs related to Law Custom (Nigivu). Of the various forms of customs, they always carry it out as well as possible. Moreover, violations of the norms that have been determined, are subject to legal sanctions called Vaya. While the person who committed the offense himself was called Novaya. ${ }^{25}$

a. Harvest Day (no-Vunja)

Culturally, the celebration of this traditional ceremony is identical to the art of rego dance. Rego is a dance of adult men and women in a circular position. Substantially the art of this dance lies in the rego of the dancers. In contrast, noVunja is a traditional ritual ceremony held when the celebration of harvest day

\section{${ }^{24} \mathrm{Ibid}$}

${ }^{25}$ Ibid. 
arrives. Thus, Rego no-Vunja is a dance that is held to welcome the 46th day of the harvest celebration. The equipment used in this ceremony is in the form of traditional clothes and some other musical instrument equipment. The Chairman of the Customary Council determines the equipment. The chairman of the Customary Council has the duty and responsibility to provide appeals and directions to the community in relation to the rules of conduct and equipment in traditional ceremonies. ${ }^{26}$

b. Funerals (Molumu)

This molumu ceremony was found in the aristocratic family environment in ancient times, especially for those who held power in the government as Magau. In implementing this traditional ceremony, there are differences between ordinary people, slaves, and Magau. The purpose and purpose of the molumu ceremony are for the spirit of the corpse to rest in peace, in the midst of the family before being buried, in addition to waiting for the Tadulako to bring their offerings in the form of the human head they were looking for outside the kingdom. Getting a human head by way of mengayau (nangae) is one of the activities and is one of the equipment in the burial ceremony of the ancient kings. The activity is mengayau (nangae). The technical implementation of the ceremony is that the carpenters are tasked with making Jumu (Coffin of the Body) which is made from intact kapok

${ }^{26}$ Hasil observasi bersama salah satu anggota Tokoh Adat Pila Nuada bagian Penasehat Hukum Adat, pada tanggal 25 Mei 2020 tree wood, in mutual cooperation. The Chairperson and Members of the Customary Council are in charge of leading the implementation of the bathing of the corpse. ${ }^{27}$

\subsection{Islamic Law Perspective on Balabe Custom}

According to the research results of al-Tayyib Khudari al-Sayyid, professor of Usul Fiqh at Al-Azhar University in Egypt in his work fi al-ijtihad ma la nassa fih, that the school which is known to use 'Urf a lot is used as a legal basis for the Hanafiyah and Maliki circles, and then by the Hanabilah and the Shafi'iyah circles. Basically, the major schools of jurisprudence agreed to accept customs as the basis for the formation of law, although in terms of numbers and details there are differences of opinion between these schools, so that 'Urf is included in the group of arguments that are disputed among scholars. The scholars of 'Usul Figh agree on the existence of 'urf alshahih, namely 'urf that does not conflict with syara'. Both those relating to 'urf al'am and 'urf al-khas and those relating to 'urf al-lafzhi and 'urfal-'amali, can be used as evidence in establishing syariah law. Based on the results of an interview with one of the informants said:

Culture, when it meets religion as long as it does not conflict with Islam, then that culture can then be used which in Islamic law is referred to as 'urf al-Sahih or cultural values that are used as

${ }^{27}$ Ibid.

e-ISSN: 2715-4580 p-ISSN: $2715-8268$ 
rules for entering religion. For example, wearing a black skullcap is a culture that comes from Muslims in Mecca. It is a good and useful culture because the skullcap can hold the hair from falling on the forehead when we pray. A culture like this is then recognized as a rule or law called al-Urf, which Islamic law allows. ${ }^{28}$

A tradition is actually a form of tradition that was developed by HinduBuddhist teachings, which were then culturally acculturated and converted by Walisongo into Islamic culture. In the past, our ancestors carried out this tradition to worship ancestral spirits or the supernatural and then used it as worship of salvation and hoping to be pleased with Allah SWT as a form of community gratitude for their Lord.

Koentjajaringrat concluded that:

The components of belief systems, ceremonial systems, and religious groups that adhere to belief systems, and carry out religious ceremonies, are the creation and result of human reason.. ${ }^{29}$

Therefore, Islam respects the human mind, puts the human mind in an honorable place, and commands humans to use their minds to examine and think

${ }^{28}$ Muhammad Asri, Tokoh Agama dan Masyarakat Palupi, Wawancara Palu, 26 Agustus 2020

29Pendapat Koentajaraningrat terhadap komponen sistem kepercayaan dikutip dalam buku "Paradigma Kebudayaan Islam" yang dituli oleh Faisal Ismail,...35 about the state of nature, in addition to dhikr to Allah SWT. the creator. ${ }^{30}$

\subsection{The use of Incence in Kalinese Balabe Custom}

The procedure for using incense in a thanking ceremony for the balabe or nolabe custom in the Kaili tribe is likened to the use of incense in the tahlilan event with other events in the balabe or nolabe custom in the Kaili tribe. The procedure is that prayers or requests in the event are in the appropriate sequences regulated in the tradition and according to the thoughts of scholars recognized by that culture. Moreover, it was designed by scholars, and scholars are required to arrange prayers or requests so that scholars arrange the sequences that have been carried out so far. ${ }^{31}$

Meanwhile, the order of reading starts with the reading of Surah AlIkhlash three times, Surah Al-Falak, and then Surah An-Nas each time. Then, read other verses such as Surah Al-Baqarah verses 1-5 and 284-286, after that the reading of Surah Ayatul Kursi, and then enter the remembrance of the remembrance and the reading of the Shalawat and then read the remembrance of another remembrance. Thus, in the wedding ceremony, it remains the same. ${ }^{32}$

In other events, the recitation is the same, and there is no difference,

${ }^{30}$ Muhaimin, et. al, Studi Islam dalam Ragam Dimensi dan Pendekatan, Cet-3, (Jakarta: Kencana, 2012), 333.

${ }^{31}$ Muhammad Asri, Tokoh Agama dan Masyarakat Palupi, Wawancara Palu, 09 November 2020

32Ibid. 
while the difference is only the length of the recited remembrance. The problem of this thanksgiving event is adjusted just as the community wishes if they want to do it. 33

The use of burning incense in the thanking event is not required to be held. According to the results of interviews conducted and stated that people who wish to burn incense, for example, those concerned do not want to use incense, then there is no obligation. ${ }^{34}$

Then, the problem with the number or amount of incense is that there is no specific requirement in how much incense will be burned in the incense holder. The incense sticks out and emits smoke and smells the place with other ingredients in the procession of burning the incense. As in the tray provides bananas, sticky rice, eggs. And other things that have entered the cultural element. And then there are other additions such as additional cakes that must be odd, for example, in one plate. However, it is not included in religion, and it's just meant as a culture. Then it does not have to be the priest who burns the incense, but Sarah's employees and the local community are also allowed to burn it. And traditional burning is the first procession in the implementation of the balabe tradition. ${ }^{35}$

The philosophy contained in the burning of incense at the thanking

${ }^{33}$ Adam, Tokoh Agama dan Masyarakat Palupi, Wawancara Palu, 10 November 2020

${ }^{34}$ Arsyid Musaera, Ketua Adat Kelurahan Palupupi, wawancara, di wawancarai di BTN Palupi Kelurahan Palupi pada Tanggal 12 Juli 2020

${ }^{35}$ Ibid. ceremony in the balabe tradition is first by using incense, then things that happen to places that use incense that has been burned will make the place smell good. Local people think that the angels will like the place. And people think that doing it in the form of dhikr or tahlil is in the Molabe custom. We feel as if we are with angels to pray to Allah SWT. Almighty. Second, the smoke that comes out of burning incense is rarely seen downwards or sideways. Unlike other smoke, the smoke produced by burning incense is always directed upwards, and the philosophy is that the upward direction of smoke will lead to and reach the Almighty and believe that Allah SWT. It is on top. And believe that the place where Allah resides is in the direction of the smoke that is pointing upwards so that it strengthens the belief that what is desired and what is prayed for will be able to reach Allah SWT. Through prayers accompanied by the fragrance of smoke coming out of the incense. 36

However, the traditional term used by the elderly has a symbol that there is indeed a place for burning incense. So, it is burned first, then sprinkled with special wood for incense that has been burned. The symbol of the use of incense for the implementation of the Balabe custom is only based on the habits of the elderly. Furthermore, suppose the use of incense burning is only a custom or tradition that is passed down from generation to generation. In that case, there is nothing that justifies the use of incense being made obligatory.

36Ibid.

e-ISSN: 2715-4580 p-ISSN: $2715-8268$ 
However, because of the old habit of burning incense at every activity, it was based on the Messenger of Allah has done it. Not to be a thing that must be used. Some of the local community also did not convey or question the incense used by the community or not. Because the balabe symbol is only a prayer that is said to Allah SWT. to be granted ${ }^{37}$

\section{Conclusions}

Basically, the major schools of jurisprudence agreed to accept customs as the basis for the formation of law. However, in terms of numbers and details, there are differences of opinion between these schools, so that 'urf is included in the group of arguments that are disputed among scholars. Islam views good custom as a form of human creation in the context of its environment (physical and non-physical). Therefore, Islam is acceptable in various forms of society that exist in this world at any time.

Pelaksanaan Adat Balabe atau Nolabe dalam pemakaian dupa acara syukuran pada Suku Kaili Di Kelurahan Palupi Kecamatan Tatang Kota Palu merupakan tata cara dalam pelaksanaan Adat Balabe/Molabe Melengkapi sebuah tradisi nenek moyang terdahulu, seperti beras pulut, pisang, kalau misalnya ada acara aqiqah membaca tahtimnya harus ada kelapanya, kue cucurunya harus ada karena itu adalah simbol orang tua dulu. Hal tersebut merupakan hasil pengamatan dalam penelitian. Bagi Suku
Kaili di Sulawesi Tengah. 'Balabe' misalnya. 'Balabe' adalah ritual adat muslim suku Kaili. 'Balabe' biasanya dilakukan setiap memen-momen tertentu, seperti hari raya idul fitri misalnya dan di hari-hari besar lainnya.

The implementation of the Balabe or Nolabe custom in the use of incense at a thanking ceremony for the Kaili Tribe in Palupi, Tatang District, Palu where there is a procedure for implementing the Balabe/Molabe tradition. Completing an earlier ancestral tradition, such as sticky rice, bananas, for example there is an aqiqah event, and reading the tahtim must be done where there is coconut, cucuru cake that must be there because it is a symbol for the elderly. This is the result of observations in the study. For the Kaili Tribe in Central Sulawesi. 'Balabe,' for example. 'Balabe' is a traditional Muslim ritual of the Kaili tribe. 'Balabe' is usually performed every certain moment, such as Eid al-Fitr and other big days.

\section{REFERENCES}

Kementerian Agama, Mushaf Famy bi Syauqin (Al-Qur'an dan Terjemah), Tangerang Banten: Yayasan Pelayan Al-Qur'an Mulia, 2014.

Adam, Tokoh Agama dan Masyarakat Palupi, Wawancara Palu, 10 November 2020

Arkunto, Suharsini, Prosedur Penelitian Ilmiah, Suatu Pendekatan Praktek, Ed.II, Cet. IX, Jakarta: Rineka Cipta, 1993.

${ }^{37}$ Ibid.

e-ISSN: $2715-4580$

p-ISSN: $2715-8268$ 
Arsyid, Kepala Adat Kelurahan Palupi, Wawancara Palu, 26 Agustus 2020.

Asri, Muhammad, Tokoh Agama dan Masyarakat Palupi, Wawancara, Palu, 26 Agustus 2020

Asykur, Abdul Ghoni, Soal-Jawab Tentang Ahlus Sunnah Wal Jama'ah, Malang: CV Bintang pelajar, 1986.

B. Milles, et. Matthew, Al, Qualitativ Data Analisys, ditejemahkan oleh Tjetjep Rohendi Rohidi dengan judul Analisis Data Kualitatif, buku Sumber tentang Motode-Metode Baru, Cet. I, Jakarta: UI-Press, 1992.

Effendi, Satria, M. Zein,, Ushul Fiqhi, Cet. Ke-3, Jakarta: Fajar Interpratama Offest, 2009.

Firdaus, Ushul Fiqih, Jakarta: Zikrul Hakim, 2004.

Handayani, A. M. S., \& Nurdin, N. (2021). Understanding Women's Psychological Well-Being in PostNatural Disaster Recovery. Medico Legal Update, 21(3), 151-161.

Haris, Masyarakat Kelurahan Palupi, Wawancara, Palu, 26 Agustus 2020.

Hidayat, Fatmah Taufik, Moh. Izhar Arif Bin Moh. Qasim, Kaedah Adat Muhakkamah dalam Pandangan Islam (Sebuah Tinjauan Sosiologi Hukum), Vol. 9, No. 1, Jurnal Sosiologi USK, 2016. (05 April 2020)

Ismail, Faisal, Paradigma Kebudayaan Islam (Studi Kritis dan Refleksi Historis), Cet. 2, Yogyakarta: Titian Ilahi Press, 1998.

Istika, Tinjauan Hukum Islam terhadap pelaksanaan Adat Molead di Desa Sioyong Kecamatan Dampelas
Kabupaten Donggala, Skripsi, Palu: IAIN Palu, 2016.

Kementrian Agama, Mushaf Famy bi Syauqin (Al-Qur'an dan Terjemah), Tangerang Banten: Yayasan Pelayan Al-Qur'an Mulia, 2014

Miharja, Jaya, Kaidah-Kaidah Al-'Urf dalam Bidang Muamalah, Vol. IV, No. 1, STAI Nurul Hakim Kediri Lombok Barat: Jurnal El-Hikam, 2011. (05 April 2020)

Mudjib, Abdul, Kaidah-Kaidah Ilmu Fiqih, Jakarta: kalam Mulia, 2001.

Muhaimin, et. al, Studi Islam dalam Ragam Dimensi dan Pendekatan, Cet-3, Jakarta: Kencana, 2012.

Musaera, Arsyid, Ketua Adat Kelurahan Palupupi, wawancara, di wawancarai di BTN Palupi Kelurahan Palupi pada Tanggal 12 Juli 2020

Nufus, Hayatun, Tinjauan Hukum Islam Terhadap Adat Empokeso di Desa Tada Timur Kecamatan Tinombo Selatan Kabupaten Parigi Mautong, Skripsi, Palu: IAIN Palu, 2014.

Nurdin, N. (2021). A Collective Action In Indonesia Local E-Government Implementation Success. International Journal Of Scientific \& Technology Research, 10(2), 160-166.

Nurdin, N., \& Yusuf, K. (2020). Knowledge management lifecycle in Islamic bank: the case of syariah banks in Indonesia. International Journal of Knowledge Management Studies, 11(1), 59-80. https://doi.org/10.1504/ijkms.2020 .105073

Nurdin, N. (2018). Institutional Arrangements in E-Government Implementation and Use: A Case e-ISSN: $2715-4580$ p-ISSN: 2715-8268 
Study From Indonesian Local Government. International Journal of Electronic Government Research (IJEGR), 14(2), 44-63. https:// doi.org/10.4018/ijegr.2018 040104

Nurdin, N., Stockdale, R., \& Scheepers, H. (2014). Coordination and Cooperation in E-Government: An Indonesian Local E-Government Case The Electronic Journal of Information Systems in developing Countries, 61(3), 1-21.

Pribadi, M., \& Nurdin, N. (2021). The Practice of Salawat Nariyah in Rural Javanese Society Indonesia: Religiosity or Sociality? Review of International Geographical Education Online, 11(5), 2545-2555.

Rasyid, N. A., \& Nurdin, N. (2021). The Diaspora of the Sufis in Indonesia: Moving From Western to Eastern Islands. International Journal of History and Philosophical Research, 9(1), 33-45.

Ristanti, Dita, Tinjauan Hukum Terhadap Adat Monik'a Suku Saluan di Keluruhan Nambo Lempek Kabupaten Banggai, Skripsi, Palu: IAIN Palu, 2016.

Rusli, R., \& Nurdin, N. (2021). Understanding Indonesia millennia Ulama online knowledge acquisition and use in daily fatwa making habits. Education and Information Technologies. doi: 10.1007/s10639021-10779-7

S Margono, Metode Penelitian Pendidikan, Cet. V, Jakarta: Rineka Cipta, 2004. Shidiq, Sapiudin, Ushul Figh, Cet. 2, Jakarta: Kencana, 2014.
Siregar, Fatahuddin Aziz, Ciri Hukum Adat dan Karaktristiknya, Vol. 4 No. 2, IAIN Padangsidimpuan: Jurnal Al-Maqasid, 2018. (05 April 2020)

Winarto, Surakhmad, Pendekatan Dalam Proses Belajar Mengajar, Bandung : PT. Remaja Rosdakarya, 1978.

Zainuddin, Faiz, Konsep Islam Tentang Adat: Telaah Adat dan 'Urf Sebagai Sumber Hukum Islam, Volume 9, No. 2, Situbondo: Jurnal Lisan Al Hal, 2015. (05 April 2020) 